\title{
Recent Trends in the Use of Pectin from Agro-Waste Residues as a Natural-Based Biopolymer for Food Packaging Applications
}

\author{
Cristina Mellinas, Marina Ramos, Alfonso Jiménez $\mathbb{D}^{\mathbb{B}}$ and María Carmen Garrigós * \\ Department of Analytical Chemistry, Nutrition \& Food Sciences, University of Alicante, ES-03690 Alicante, \\ San Vicente del Raspeig, Spain; cristina.mellinas@ua.es (C.M.); marina.ramos@ua.es (M.R.); \\ alfjimenez@ua.es (A.J.) \\ * Correspondence: mc.garrigos@ua.es
}

Received: 31 December 2019; Accepted: 28 January 2020; Published: 3 February 2020

check for updates

\begin{abstract}
Regardless of the considerable progress in properties and versatility of synthetic polymers, their low biodegradability and lack of environmentally-friendly character remains a critical issue. Pectin is a natural-based polysaccharide contained in the cell walls of many plants allowing their growth and cell extension. This biopolymer can be extracted from plants and isolated as a bioplastic material with different applications, including food packaging. This review aims to present the latest research results regarding pectin, including the structure, different types, natural sources and potential use in several sectors, particularly in food packaging materials. Many researchers are currently working on a multitude of food and beverage industry applications related to pectin as well as combinations with other biopolymers to improve some key properties, such as antioxidant/antimicrobial performance and flexibility to obtain films. All these advances are covered in this review.
\end{abstract}

Keywords: pectin; food packaging; active compounds; agro-waste residues; circular economy

\section{Introduction}

Biopolymers are gaining their market share in the plastics industry by their intrinsic biodegradable character combined with interesting properties for specific applications. Biopolymers can be obtained/ extracted from natural sources, biosynthesized by living organisms or chemically synthesized from biological materials [1]. In addition, their natural-based origin, i.e., from renewable sources represents a great advantage over plastic commodities since their use decrease dependence from petroleum while preserving and even improving important material properties. There has been an increasing interest for the use of biopolymers in packaging, medicine, agriculture, and other sectors. Different types of carbohydrates, such as starch and cellulose, as well as other polysaccharides, such as alginates and pectin, as well as their combinations with animal-protein-based biopolymers, such as silk, wood, gelatin, collagen, chitosan/chitin, gums, plant-based proteins and lipids offer the possibility of rendering interesting applications for these advanced sectors. All these biopolymers offer interesting advantages in their use, such as their renewable origin, biocompatibility, barrier properties to moisture and/or gases, non-toxicity, non-polluting characteristics, mechanical integrity and relative low cost.

The increase in the use of biopolymers has caused that their global market is expected to reach around 10 billion US Dollars by 2021, growing by almost 17\% over the forecast period 2017-2021. Western Europe covers the largest market segment, accounting for $41.5 \%$ of the global market while other regions are rapidly increasing their market share [2].

In addition, another important possibility offered by the use of biopolymers is their potential to be synthesized from the non-edible parts of plants or animals, avoiding the risk of depleting food 
from local communities, most of them in under-developed regions. Figure 1 shows the main types of biopolymers that can be obtained from biomass waste as well as some examples of their sources. They can be divided into three large groups: proteins, lipids and polysaccharides. The protein-based biopolymers can be obtained from both animal and vegetable wastes. For example, slaughterhouse wastes are a good source of proteins from animal origin, like gelatin. These wastes comprise the inedible tissues/parts of the animals slaughtered for the production of meat [3]. Among the proteins from plant origin, soy protein isolate is a good option to develop new materials due to its composition and excellent processing ability by gelling, emulsifying ability and water and oil holding capacity [4].

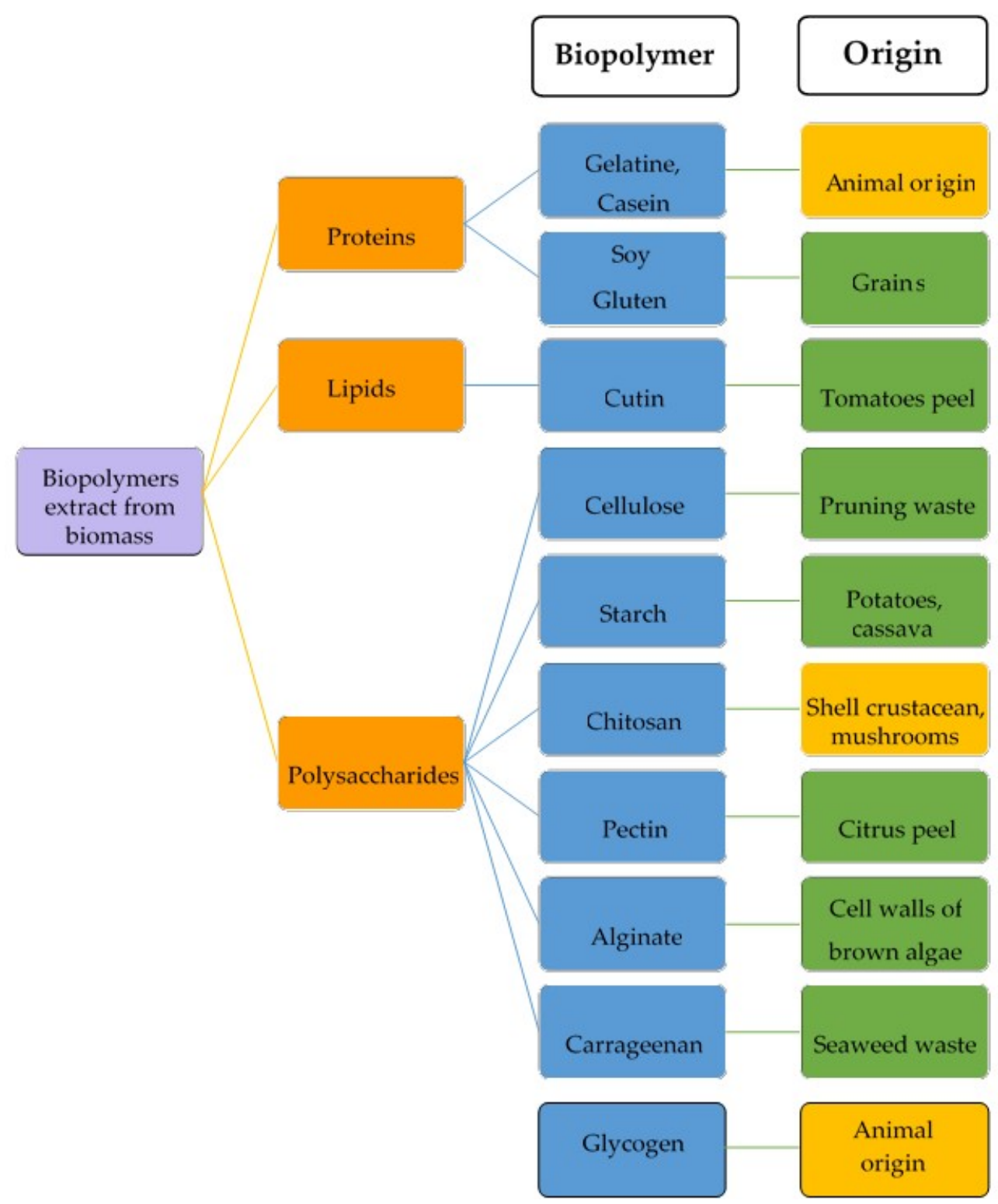

Figure 1. Different types of biopolymers obtained from animal and vegetable wastes.

Lipid-based polymers have been used in the last few years in food packaging or 3D printing materials. Their extraction from the natural sources is a necessary step to render isolated fatty acids to be further used in esterification reactions. For example, cutin extracted from tomato by-products [5] and lipids extracted from algae [6] have shown great potential to obtain specific fractions for the production of films with high barrier to water due to the repulsion caused by their high hydrophobic behaviour. 
Polysaccharide-based polymers are the last group in Figure 1. These biopolymers are characterized by their biodegradable, biocompostable, sustainable and non-toxic characteristics. Additionally, polysaccharides are more thermally stable than other biopolymers, like lipids and proteins, since they are not irreversibly denatured via heating. However, their main disadvantages are the high sensitivity to moisture and low mechanical resistance [7]. In order to limit these problems, two different approaches have been proposed: the incorporation of different reinforcing additives to the polysaccharides matrices $[8,9]$ and the combination with different polymers to obtain blends $[10,11]$ or multilayer films $[12,13]$. The improvement in polysaccharides properties have permitted the extension of their use by the food industry in the last few years [14,15].

Pectin is one of the major structural polysaccharides present in many higher plant cells allowing primary cell wall extension and plant growth. It could be extracted and applied as an anionic biopolymer, soluble in water. A large number of recent articles have highlighted the advantages of using pectin over conventional polymers. Therefore, pectin is increasingly important for a multitude of food packaging applications, such as a thickening and gelling agent, colloidal stabilizer, texturizer, and emulsifier [16-18], a coating on fresh and cut fruits or vegetables [19-21] and as micro and nano-encapsulating agent for the controlled release of active principles with different functionalities [22]. Rodsamran et al. [16] reported that bioactive pectin films can retard soybean oil oxidation during 30 days of storage. Furthermore, Sucheta et al. [19] found that a pectin-corn flour-based coating significantly reduced the weight loss and decay per cent of tomatoes, delaying respiration with retention of biochemical quality of tomatoes. Additionally, polymeric blends of hydrocolloids obtained from chia seeds and apple pectin where developed with the aim to obtain antioxidant polymer blend films using the 2,2-diphenyl-1-picrylhydrazyl (DPPH) assay to estimate their antioxidant activity [10].

Pectin has been also extracted from waste biomass by using innovative methods, contributing to waste management in agriculture and food processing industries. Different pectin sources can be used, such as by-products of juice manufacturing as well as orange, mango, banana, lime and pomegranate peels and seeds. Therefore, this review aims to present and discuss the potential of pectin as a bio-based material in food packaging applications by its efficient extraction from waste biomass, while addressing a solution to the important environmental problems caused by the disposal of residues and by-products in the food sector.

\section{Pectin}

\subsection{Pectin Structure}

Pectin is a complex heteropolysaccharide and a major multifunctional component of the cell wall in many terrestrial plants. It is usually found in association with other compounds like cellulose, lignin or polyphenols present in the cell wall of plants [22]. Pectin is mainly composed of galacturonic acid units (Figure 2). The carboxyl groups of uronic acid residues can be present in different forms in the polymer structure, either free or as a salt form with sodium, calcium or other small counter-ions. In some cases, they can be also present as naturally-esterified groups, particularly with methanol, depending on the pectin source and/or the extraction method. Due to the presence of free carboxyl groups, pectin solutions exhibit acidic $\mathrm{pH}$ values. Galacturonic acid comprises approximately $70 \%$ of the pectin composition, depending on the plant species, and all the pectic polysaccharides contain galacturonic acid linked at the O-1 and the O-4 positions [23]. Pectin has a linear anionic backbone which regions showing no side chains known as "smooth regions" and regions with non-ionic side chains known as "hairy regions" [24].

Different pectin structural domains may be distinguished (Figure 2), influencing their properties depending on pectin proportions [23]. 


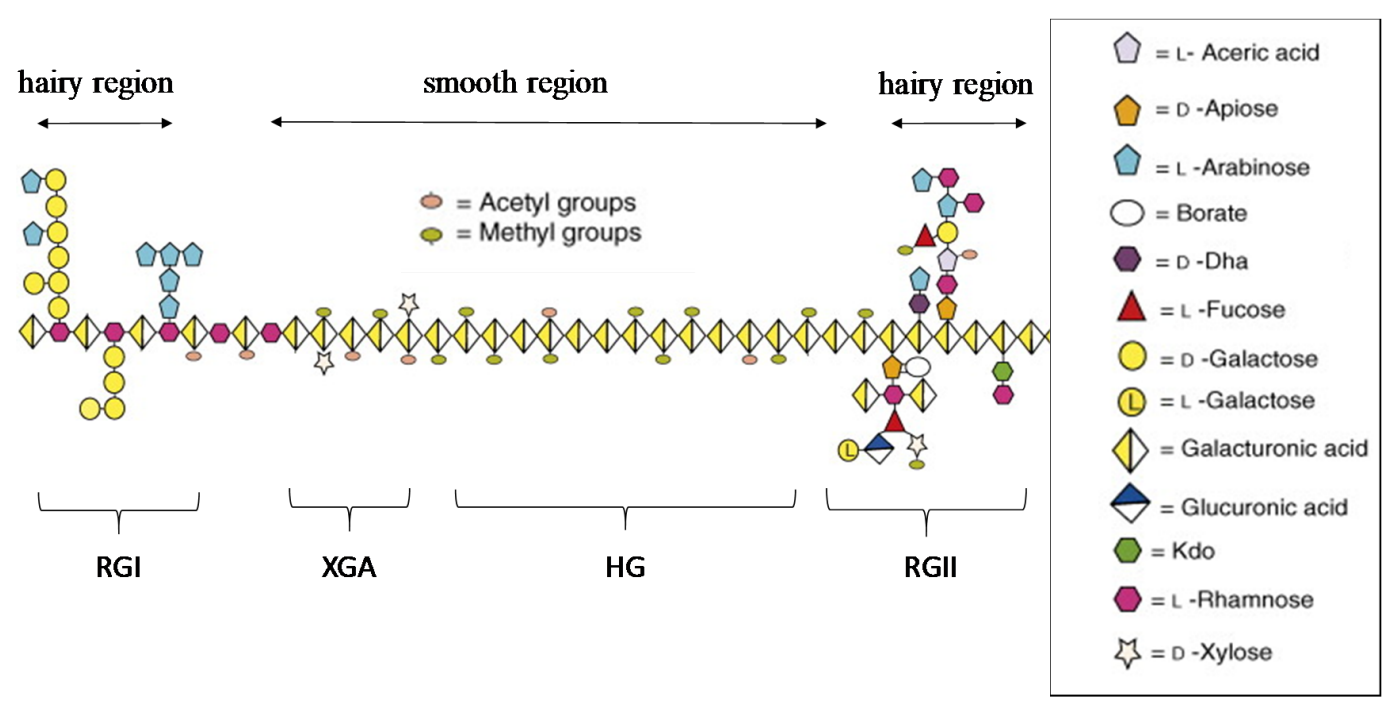

Figure 2. Schematic pectin structure, adapted from [23].

Homogalacturonan (HG): HG is the major domain of pectin in cell walls of plants, representing approximately $65 \%$ of the total pectin content. It is formed by galacturonic acid residues, linked by $\alpha$ $(1 \rightarrow 4)$ bonds, and their carboxyl groups are partially methyl esterified at position 6 . Additionally, this domain may be acetylated at position 2 or 3 depending on the origin of the pectin. These domains are the main constituents of the above-mentioned "smooth regions" [24].

Rhamnogalacturonan I (RG-I) contains about $20 \%-35 \%$ of the total pectin and shows a more complex structure than HG. It contains repeated units of disaccharides consisting of L-rhamnose and galacturonic acid that can be also acetylated in the positions 2 or 3 . It could have up to 100 units of $(1,2)-\alpha$-L-Rha-(1,4)- $\alpha$-D-GalA. In addition, large amount of L-rhamnose structures are substituted at $\mathrm{O}-4$ by different neutral sugars such as L-galactose and L-arabinose [23].

Rhamnogalacturonan II (RG-II) contains about 10\% of the total pectin and it is the structurally more complex component. Despite it is a relatively minor component in the pectin chain, RG-II plays a central role in the structure of plant cell walls. Small structure modifications of RG-II lead to reductions in the dimers formation and they can cause severe growth defects. So, dimerization of RG-II in the cell wall may be crucial for the normal growth and development of plants. This domain is composed of an HG backbone of (at least eight) 1,4-linked $\alpha$-d-GalA residues decorated with side branches consisting of different types of sugars (rhamnose, fucose, xylose, galactose, apiose or aceric acid) in over 20 different types of linkages $[23,25,26]$.

It is generally believed that the pectic polysaccharides are covalently bonded with high crosslinking densities since harsh chemical treatments or digestion by pectin-degrading enzymes are required to isolate HG, RG-I, and RG-II from each other. In addition, it has been reported that other components, such as xylogacturonan (XGA) and apiogalacturonan (AP), could replace the galacturonic acid units in some parts of the pectin chain [23]. The complexity of the pectin structures increases since it can be changed during the plant storage, extraction and processing, resulting in modifications of pectin functionalities and hindering its structural elucidation. It has been reported that the variations in chain lengths in each of the different domains are not the same, because HG and RGII have a highly homogeneous structure while RGI exhibits a wide heterogeneity in its composition [26].

\subsection{Type of Pectins}

The degree of esterification (DE) is an important parameter for the definition of the pectin applications and it is defined as the percentage of carboxyl groups esterified present in the structure of pectin. DE is often used to classify the different types of pectins (Figure 3). Depending on the DE different emulsifying, texturizing and gelling properties are observed. In general, when the DE 
increases, the water solubility decreases due to the hydrophobic nature of esters with long hydrocarbon chains. In contrast, when the DE increases the gelation rate also improves resulting in rapid gelation pectins [27]. Furthermore, the amount and composition of neutral sugars and the overall molecular weight of pectins have a great influence in their rheological properties [28].

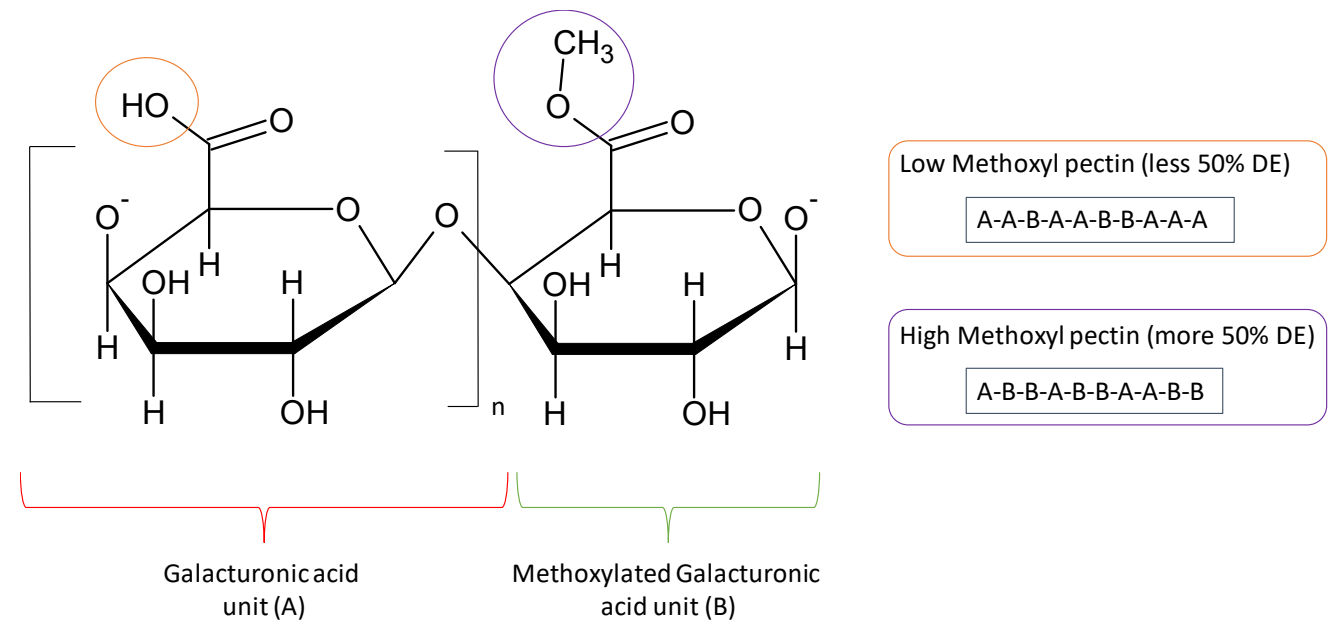

Figure 3. Structure of low and high methoxyl pectins.

High methoxyl pectin (HMP) shows DE higher than 50\% and it is mainly used in the food industry by its thickening and gelling properties. It has been reported that HMP requires high amount of sugars for gelation and it is very sensitive to acidity [29]. HMP forms gels at low pH values and high concentrations of soluble solids due to the presence of hydrogen bonding and hydrophobic interactions between the pectin chains. Neutral sugars like sucrose play different roles in gelation through regulation of the hydrophobic interaction or directly binding to the polymer chains of HMP. Gels are formed when HG portions are cross-linked to form three dimensional crystalline networks in which water and other solutes are trapped [30]. The mechanism of formation of HMP gels is complex and it has been the subject of many investigations in the last decades. The glass transition theory has been proposed to explain the formation of HMP gels. Due to the high viscosity of molecules an arrest of the system kinetics occurs, giving as a result the formation of the gel due to the increased concentration of co-solutes and decrease in the water content. The transition from sol to gel behaviour is due to the combined effect of HMP and sucrose at $\mathrm{pH} 3$, and occurs when excluded volume effects and attractive interactions are capable to give rise to an incipient three-dimensional network [31]. In addition, the effect of monovalent cations has been evaluated under different alkaline conditions $(\mathrm{NaOH}$ and $\mathrm{KOH})$ at different pectin concentrations. It was suggested that HMP gel is formed through different mechanisms, such as de-esterification, self-aggregation, and entanglement under alkaline conditions. $\mathrm{Na}^{+}$or $\mathrm{K}^{+}$bind to dissociated carboxyl groups in HMP due to electronic attraction and this behaviour enables HMP molecules to move closer to each other, thereby improving gel network formation [32].

The emulsifying properties of HMP have been investigated by Jiang et al. in binary water-ethanol systems. They suggested that ethanol reduces the electrostatic repulsion and promotes pectin aggregation [33]. When HMP was mixed with the water-ethanol mixtures, the helix structure was broken, and electrostatic repulsion decreased. The compact and hydrophobic conformation enables pectin to adsorb better on the oil-water interface. The obtained emulsion showed good stability when using $21 \%$ of ethanol in the mixture.

Low methoxyl pectin (LMP) shows DE lower than $50 \%$ and it is generally formed by the de-esterification of HMP. Different agents can be used for the preparation of LMP from HMP, such as alkalis like sodium hydroxide or ammonia, enzymes (pectin methyl esterase) and concentrated acids [34]. 
LMP is widely used by the food industry to form low sugar-content jams as it does not require large amounts of sugar for gelation. It shows less sensitivity towards acidity and requires $\mathrm{Ca}^{2+}$ ions to form gels. The gelation mechanism in LMP is mediated by the formation of calcium bonds between two carboxyl groups from two chains in close contact [28]. Recently, Han et al. studied the effect of the calcium concentration, $\mathrm{pH}$, soluble solids, and pectin concentration on the gel strength of LMP gels and they proposed different mechanisms of formation of pectin gels based on their rheological properties [35]. They observed that $\mathrm{pH}$ values close to the isoelectric point $(\mathrm{pH}=3.50)$ and high calcium concentrations enhanced the storage modulus and gel strength by formation of calcium bridges at dissociated carboxyl groups. In addition, the sucrose content improved the gel strength because the neutral sugars provide hydroxyl groups to stabilize the gel and contribute to the formation of hydrogen bonds to immobilize free water. On the other hand, the formation of LMP gels under alkaline conditions was tested by Yang et al. [36]. They suggested that LMP can form relatively stable gels in the $\mathrm{pH}$ range of 3.5-9.5 using $\mathrm{NaOH}$ as $\mathrm{pH}$ regulator. In addition, they evaluated the effect of calcium concentration in the thermal and structural properties of the LMP gels and they concluded that the presence of calcium ions not only reduced the thermal stability but also the crystalline degree of LMP.

\section{Sources of Pectin}

Due to the high potential of pectin-based polymers, the extraction of pectin from biomass waste has been widely studied. Table 1 summarizes several published works based on the extraction of pectin from agro-waste sources.

Table 1. Different raw materials and extraction methods to obtain natural pectin.

\begin{tabular}{|c|c|c|c|c|c|c|}
\hline \multirow{2}{*}{ Raw Material } & \multirow{2}{*}{$\begin{array}{l}\text { Extraction } \\
\text { Method }\end{array}$} & \multicolumn{4}{|c|}{ Conditions } & \multirow{2}{*}{ Ref. } \\
\hline & & $\mathrm{T}\left({ }^{\circ} \mathrm{C}\right)$ & Time (min) & LSR (mL/g) & Other Variables & \\
\hline Eggplant peel waste & HAE & 90 & 30 & 40 & - & [37] \\
\hline Orange peel waste & HAE & 80 & 60 & 17.1 & pH: 1.5 & [38] \\
\hline Orange peel waste & HAE & 75 & 300 & 20 & pH: 2.5 & [39] \\
\hline Orange peel waste & HAE & 95 & 120 & 6 & pH: 1.6 & [40] \\
\hline Pomelo peel waste & HAE & 90 & 120 & 30 & pH: 2 & [41] \\
\hline Pomegranate peel waste & HAE & 70 & 120 & 10 & - & [42] \\
\hline Apple peel waste & HAE & 85 & 120 & 25 & - & [43] \\
\hline Cashew apple pulp & HAE & 100 & 120 & 5.15 & - & {$[44]$} \\
\hline Chamomile Waste & HAE & 90 & 60 & 20 & pH: 1.2 & {$[45]$} \\
\hline Durian rind waste & HAE & 85 & 60 & 9 & pH: 2.5 & [46] \\
\hline Hibiscus (sabdariffa L.) & HAE & 100 & 30 & 20 & pH: 2.5 & [47] \\
\hline Banana peel waste & HAE & 86 & 360 & 50 & pH: 2 & [48] \\
\hline Banana peel waste & HAE & 90 & 30 & 20 & pH: $1.5,6$ & [49] \\
\hline Mango peel waste & HAE & 90 & 120 & 20 & - & [50] \\
\hline Jackfruit peel waste & HAE & 138 & 9 & 17 & - & [51] \\
\hline Jackfruit peel waste & HAE & 90 & 60 & 10 & - & [52] \\
\hline Jackfruit peel waste & HAE & 90 & 60 & 20 & - & [53] \\
\hline Passion fruit rind & HAE & 98 & 90 & 50 & - & [54] \\
\hline Tomato husk waste & HAE & 100 & $15-25$ & 30 & - & [28] \\
\hline Orange peel waste & $\mathrm{HC}$ & $14.6-96$ & 270 & 2.86 & - & [55] \\
\hline $\begin{array}{l}\text { Artichoke (Cynara } \\
\text { scolymus L.) }\end{array}$ & EAE & 50 & 2880 & 15.4 & pH: 5, Enzyme: $10.1 \mathrm{Ug}^{-1}$ & [56] \\
\hline Sisal Waste & EAE & 50 & 1200 & 15 & Enzyme: $88 \mathrm{Ug}^{-1}, \mathrm{pH}: 5$ & [57] \\
\hline Tobacco waste & MAE & - & 4 & 20 & $550 \mathrm{~W}, \mathrm{pH}: 1.8$ & [58] \\
\hline Cocoa Pod Husk waste & SWE & 121 & 30 & 27.5 & $103.4 \mathrm{bar}$ & [59] \\
\hline Custard apple peel waste & UAE & 63 & 18 & 21 & pH: 3 & [60] \\
\hline Mango peel waste & UAE & 85 & 10 & 7.6 & $497.4 \mathrm{~W} / \mathrm{cm}^{2}, \mathrm{pH}: 2$ & {$[61]$} \\
\hline Sisal Waste & UAE & - & 60 & 15 & 450W, pH: 4 & [57] \\
\hline Passion fruit rind & UAE & - & 10 & 20 & $135 \mathrm{~W}$ & [62] \\
\hline Jackfruit peel waste & UAE-MAE & 86 & 29 & 48 & - & {$[63]$} \\
\hline
\end{tabular}

HAE: Hydrothermal-assisted extraction; UAE: Ultrasound-assisted extraction; HC: Hydrodynamic cavitation; MAE: Microwave-assisted extraction; SWE: Subcritical water extraction; EAE: Enzyme-assisted extraction. 
The peels of citrus fruits have been reported as the main source to obtain pectin at the industrial scale due to their good properties and high extraction yield. Hydrothermal extraction is the most usual method to obtain pectin from orange peels and it involves high temperatures $\left(75-95^{\circ} \mathrm{C}\right)$ and extraction times (60-300 $\mathrm{min}$ ). Additionally, in all cases, the hydrothermal extraction of pectin takes place under acidic conditions using water as solvent. Pectin is very soluble in water and the acid medium decrease the presence of other compounds like polyphenols increasing extraction yields and helping to maintain the quality of the extracted pectin [38-41]. Other methods have been tested to reduce extraction times in citrus by-products. For example, microwave-assisted extraction (MAE) has been used in lime [64] and pomelo peels [65] reducing the extraction times to five and two minutes, respectively. However, high microwave powers $(700-1100 \mathrm{~W})$ were required to achieve these results. The hydrodynamic cavitation method was also used to obtain pectin derived from orange peel waste. Although a large decrease in the amount of solvent $(2.86 \mathrm{~mL} / \mathrm{g}$ of dry waste) was observed, long extraction times were also needed (270 $\mathrm{min})$ [55].

The use of other sources to obtain pectin-based polymers in good grade and quality has been proposed in the last few years, such as eggplant peel [37], chamomile waste [45], cocoa pod husk [59,66], banana peel [49], mango peel [50,61,67] or tomato husk [28]. Tropical fruits have been also studied in the last years to obtain HMP. For example, passion fruit rind [54,62], durian rind [46] or jackfruit peels $[51,52,63]$ have been proposed as interesting sources of pectins. Hydrothermal extraction is also the most used method in these types of wastes. Ultrasound-assisted extraction (UAE) has been also tested in passion fruit rind using $450 \mathrm{~W}$ and a water to dry sample ratio of $20 \mathrm{~mL} / \mathrm{g}$ for 10 minutes. Results showed that the obtained pectin was mainly formed by homogalacturonans. Furthermore, their high degree of methylation indicated that the passion fruit pectin could be applied in gel forming products [62].

The use of innovative and sustainable extraction techniques is heading towards the study of hybrid techniques with the objective of combining their advantages, such as in the case of MAE and UAE. Pectin has been obtained from sisal waste by the combination of enzymatic and ultrasonic processes as an efficient strategy for the production of high-quality pectins since the enzymatic treatment disrupt the links between cellulose and xyloglucans in the cell wall of sisal and then the ultrasonic treatment produces mechanical destruction of the sisal structure to improve the release of pectin [57].

Finally, the introduction of new extraction techniques can be a great initial investment for companies since they offer the possibilities to get specific extractions of high added value purified compounds, although the costs of microwave or ultrasonic based equipment are higher than those of conventional extraction equipment, but in the long term, these devices are more profitable since the energy consumption, extraction time and the amount of expensive reagents used during pectin extraction are reduced $[68,69]$.

\section{Pectin-Based Materials for Food Packaging Applications}

Pectin is a versatile compound that can be used to develop different materials in many food applications such as thickening and gelling agent, colloidal stabilizer, texturizer and emulsifier. These important applications are not limited to food processing, but also to packaging, coatings on fresh and cut fruits or vegetables and as microencapsulating agents (Table 2). Pectin is soluble in pure water and insoluble in organic solvents. Moreover, when dry pectin is mixed with water it tends to hydrate very rapidly, forming clumps. This behaviour is due to the formation of dry spheres of pectin contained in a highly hydrated outer coating. In order to eliminate these clumps, a vigorous and long agitation time is required [70]. In general terms, diluted pectin solutions present a Newtonian behaviour, but at high concentrations they show non-Newtonian behaviour, corresponding to pseudo-plastic characteristics. It was observed that the decrease in solubility and increase in viscosity contribute to increase the gelation capacity, i.e., the pectin concentration has a positive effect in gelation capacity and viscosity but a negative effect in solubility. Although it was stated that pectin properties are mainly 
dependent on structure, particularly DE [22,71], film forming, gelling and emulsifying properties should be also considered.

Table 2. Different types of pectin-based materials used in food packaging applications.

\begin{tabular}{|c|c|c|c|c|}
\hline Type & Polymer Matrix & Additive & Application & Ref. \\
\hline Film & LMP-bitter vetch protein & Transglutaminase & Drug delivery system & [72] \\
\hline Film & LMP & Ascorbic acid & AO system & [73] \\
\hline Film & HMP & Clove EO & AM system & [74] \\
\hline Film & HMP & Marjoram EO & AO system & [75] \\
\hline Film & HMP-Gluconaman & Tea extract & $\mathrm{AO} / \mathrm{AM}$ system & [76] \\
\hline Film & Pectin-Pullulan & AgNPs & AM system & [77] \\
\hline Film & HM-Apple pectin & Chia seed hydrocolloid & AO system & [10] \\
\hline Film & Chitosan-Starch-Pectin & $\begin{array}{l}\text { Mint and rosemary oils } \\
\text { Nisin }\end{array}$ & $\mathrm{AO} / \mathrm{AM}$ system & [78] \\
\hline Film & Fish gelatine-HMP & $\begin{array}{c}\text { Hydroxytyrosol, } \\
\text { dihydroxyphenylglycol }\end{array}$ & Preservation of beef meat & [79] \\
\hline Film & HMP & Red cabbage extract & $\mathrm{pH}$ indicator & [80] \\
\hline Film & Chitosan-HMP & Anthocyanin & pH indicator & [81] \\
\hline Nanocomposite & Pectin & AgNPs, laponite & $\begin{array}{c}\text { Coating polypropylene to } \\
\text { improve barrier/AM } \\
\text { properties }\end{array}$ & [82] \\
\hline Nanocomposite & Pectin & $\mathrm{Ag} / \mathrm{AgCl}-\mathrm{ZnONPs}$ & AM system & [83] \\
\hline Nanofiber & HMP & AgNPs & Reinforcement, AM & [84] \\
\hline Nanofiber & $\begin{array}{c}\text { LMP } \\
\text { Polyethylene oxide }\end{array}$ & - & Reinforcement & [85] \\
\hline Aerogel & Amidated pectin & $\mathrm{TiO}_{2}, \mathrm{NPs}$ & $\begin{array}{l}\text { AM under dark and UV } \\
\text { illumination conditions }\end{array}$ & [86] \\
\hline Hydrogel & LMP-Chitosan & Garlic and holy basil EOs & $\begin{array}{c}\text { Incorporate to cellulose } \\
\text { bag to improve AM } \\
\text { properties }\end{array}$ & [87] \\
\hline Oleogel & HMP & $\begin{array}{l}\text { Camelia oil } \\
\text { Tp-Palmitate }\end{array}$ & Drug delivery system & [88] \\
\hline Emulsion & HMP & Clove EO & Bream fillets coating & [89] \\
\hline Microemulsion & Chitosan-HMP & Cinnamaldehyde & AM system & [90] \\
\hline Nanoemulsion & Food-grade pectin & Curcumin and garlic EOs & Coating chicken fillets & [91] \\
\hline Nanoemulsion & $\mathrm{HMP}$ & $\begin{array}{c}\text { Oregano, thyme, lemongrass, } \\
\text { mandarin EOs }\end{array}$ & AM system & [92] \\
\hline Nanoemulsion & HMP & Lemongrass EO & $\begin{array}{l}\text { Addition in Cassava starch } \\
\text { film to improve } \\
\text { biodegradation properties }\end{array}$ & [93] \\
\hline Multilayer emulsion & HMP-Chitosan & Astaxanthin & $\begin{array}{l}\text { Release of hydrophobic } \\
\text { carotenoids }\end{array}$ & [94] \\
\hline
\end{tabular}

EO: essential oil; AM: antimicrobial; AO: antioxidant.

\subsection{Pectin-Based Films}

Casting is the most used technique to obtain pectin-based films [10,73-75,79]. Pectin solutions (around 2-3 $\mathrm{wt} \%$ ) are mixed with the appropriate amount of plasticizer, commonly glycerol [95]. Then, the film forming solution is dried under controlled conditions of temperature and humidity forming a thin film. The incorporation of active agents, such as antimicrobial and/or antioxidant compounds, is performed after the incorporation of the plasticizer to obtain good compatibility between all components during the film processing [96-98]. Recently, Gouveira et al. [99] have reported the successful production of pectin-based films by using thermo-compression moulding of raw pectin with a natural deep eutectic solvent. The visual aspect of the obtained films was acceptable, since they were yellowish, visually homogenous, semi-transparent and without apparent pores, also showing high tensile strength and water resistance.

Pectin offers good compatibility with other biopolymers, such as proteins [73], lipids [100], other natural polysaccharides [101] or even synthetic biopolymers [82]. All these combinations represent alternatives when considering the final application of the obtained films. Both types of pectin (HMP and LMP) can form thin films under specific conditions. For example, LMP has been used as an appropriate matrix in new antioxidant systems with ascorbic acid as active additive by using casting as the processing method [72]. LMP was heated to $90^{\circ} \mathrm{C}$ and then, glycerol and ascorbic acid were 
incorporated to the solution. Finally calcium chloride was added as the crosslinking agent to permit the formation of consistent and homogeneous pectin-based active films. In contrast, the addition of calcium ions is not necessary to develop films based on HMP, but low $\mathrm{pH}$ values and high sugar concentrations are needed to produce thin films. Nisar et al. [74] produced HMP films with antimicrobial properties incorporating clove essential oil by the casting method. Film forming solutions $(3 \% w / v)$ were prepared by rehydrating pectin in sterile deionized water for $12 \mathrm{~h}$ at $20^{\circ} \mathrm{C}$. Glycerol was used as plasticizer at 30 wt \% with magnetic stirring at $70{ }^{\circ} \mathrm{C}$ while $\mathrm{pH}$ was adjusted to 4.5 . The clove essential oil with an emulsifier to improve the oil dispersion in the film aqueous solution were incorporated into the film forming solutions at different concentrations. A great integration of the clove essential oil into the polymer matrix was observed with a positive significant influence on the physico-chemical and functional properties, in particular barrier, mechanical, antioxidant and antimicrobial.

Marjoram, mint and rosemary essential oils are some of the active additives incorporated into the pectin matrix to get functionalities to these biopolymer materials. Almasi et al. [75] evaluated the effect on physico-chemical properties of marjoram essential oil in pectin films for food packaging applications. In order to prevent the degradation of the highly volatile essential oil and to control its release into food, it was incorporated using nanoemulsions and Pickering emulsions. Both types of emulsions combined the use of the essential oil and a low molecular weight surfactant with whey protein isolate or inulin as nanocarriers. Results obtained through X-ray diffraction (XRD), Fourier transformed infrared spectroscopy (FTIR) and field emission scanning electronic microscopy (FESEM) confirmed the high compatibility between pectin and both emulsions. The encapsulation of the essential oil through Pickering emulsions provided significantly slower releasing rates through the films when compared to nanoemulsions. For these reasons, authors concluded that the active pectin films containing Pickering emulsions showed the best potential to be used in active food packaging due to the slow release of the essential oil increasing food shelf-life. On the other hand, the synergic effect between mint and rosemary essential oils and nisin was investigated by Akhter et al. [78] using chitosan, starch and pectin blends. These authors concluded that the inclusion of rosemary essential oil and nisin improved the water barrier properties, tensile strength and thermal stability of the active biocomposites. Additionally, the combination of these compounds in a pectin matrix showed high antimicrobial action against some pathogenic strains (Bacillus subtilis, Escherichia coli and Listeria monocytogenes).

Furthermore, extracts derived from plants have been proposed to improve the functional properties of pectin. For example, tea extracts were incorporated into a HMP/Glucomannan blend. The influence of the addition of tea extracts at different concentrations (from $1 \%$ to $5 \% \mathrm{wt} \%$ on a dry basis) on the structural and physical properties of the blend, as well as on the antioxidant and antimicrobial activities were evaluated [76]. The authors found that concentrations of tea extract lower than $2 \mathrm{wt} \%$ improved all these properties but the effect was negative at high concentrations since some aggregation in the biopolymer macromolecules was observed. Red cabbage extract has been proposed for the development of a smart film based on HMP for meat and fish products. [80]. Red cabbage extract is rich in anthocyanins, showing the ability to change the colour of the biopolymer matrix at different $\mathrm{pH}$ values. It is known that the degradation of animal proteins produces an increase in $\mathrm{pH}$ due to the liberation of nitrogen compounds that can be monitored using a colorimetric sensor based on pectin and the red cabbage extract, offering innovative applications of pectin to the food industry [80]. These results showed the significant colour change in edible films when they are exposed to the headspace of meat and fish products at $21^{\circ} \mathrm{C}$ and $4{ }^{\circ} \mathrm{C}$, respectively.

The physical and functional properties of pectin-based films can be also modified by the combination of commercial pectin with corn flour and beetroot powder to minimize post-harvest decay, reducing ripening and improving sensorial properties of tomatoes [19]. In this study, results showed that pectin-based films protect from losses of polyphenols improving the antioxidant activity of these materials. In addition, other properties are modified due the presence of the edible coating. Pectin can modify the atmosphere around the fruit and/or vegetables, altering oxygen levels inside the fruit, retarding production of ethylene and, thus, limiting their physiological decay. In this work, 
pectin-based films showed low hydrophobicity to get optimum gas and water vapour permeability; reducing the ripening induced quality degradation in terms of texture and loss of bioactive compounds during storage.

Finally, the incorporation of nanoparticles to improve the physical and functional properties of pectin-based films has been evaluated. Biocomposites formed by a biopolymer matrix with metal or metal oxide nanoparticles are gaining importance in active food packaging since they could play a double role. On one hand, nanoparticles can act as nanofillers to enhance the mechanical and barrier properties of the biopolymer matrix and, on the other hand, they can interact directly with food due to their potential antimicrobial/antioxidant activity [102]. The effect of silver nanoparticles (AgNPs) has been tested in pectin, pullulan (a polysaccharide produced by fermentation by the Aureobasidium pullulans fungus), and pectin/pullulan blends [77]. Silver nanoparticles improved the mechanical properties of pullulan/AgNPs and pullulan/AgNPs/pectin composites while also showing high antimicrobial activity against foodborne pathogens, especially Salmonella Typhimurium, Escherichia coli and Listeria monocytogenes. AgNPs have been also proposed to develop nanocomposites based on pectin to be used as coatings for other polymer matrices with the aim to improve their barrier and mechanical properties as well as providing antimicrobial/antioxidant properties. Nanocomposites based on pectin with AgNPs and laponite have been evaluated to get a significant reduction in the oxygen transmission rate and water vapour transmission rate respect to neat polypropylene films taken as control [82]. The application of these new films showed antimicrobial activity against Gram-negative and Gram-positive bacteria, Escherichia coli and Staphylococcus aureus, respectively.

Other types of nanoparticles have been tested in pectin as the polymer matrix. Titanium oxide nanoparticles $\left(\mathrm{TiO}_{2} \mathrm{NPs}\right)$ were incorporated at low concentrations (0-2 wt \%) into biodegradable starch-pectin (3:1) films to improve their mechanical and barrier properties as well as their potential as antioxidant systems for food packaging applications [103]. In addition, visible and UV radiation was completely absorbed or scattered in these films by the addition of $\mathrm{TiO}_{2} \mathrm{NPs}$ to get starch-pectin films with potential as UV screening packaging materials. On the other hand, the addition of halloysite nanotubes (HNT) offers great advantages to develop advanced food packaging materials. The effect of HNTs with salicylic acid [104], rosemary [97] and peppermint [105] essential oils in pectin films has been reported. HNTs showed high compatibility with pectin films improving their mechanical, thermal and moisture barrier properties [97,104]. The antimicrobial performance of these films was also improved due to the increase in the release rate of active compounds [97]. In fact, the antimicrobial activity of pectin-based films against Gram-negative Escherichia coli ATCC 25922, Salmonella Typhimurium ATCC 14028, Pseudomonas aeruginosa ATCC 10145, and Gram-positive Staphylococcus aureus ATCC 29213 was studied by the disk diffusion method, suggesting the effective antimicrobial properties of these functionalized films [104].

\subsection{Emulsions and Gels}

Pectins are widely used in the food industry as emulsifier and gelling agents. The ability of pectins to form gels under specific conditions has been used to obtain aerogels [86,106], hydrogels [87,107] or oleogels $[88,108]$. In particular, hydrogels are the most popular gel compositions used in food packaging, since they are able to absorb large amounts of water or other biological fluids inside their structure. For example, Torpol et al. studied the encapsulation of two different antimicrobial compounds: garlic and holy basil essential oils in chitosan-pectin hydrogel beads [87]. The entrapment of essential oils in the matrix structure was successful and it showed antimicrobial capacity against Bacillus cereus, Clostridium perfringens, Escherichia coli, Pseudomonas fluorescens, Listeria monocytogenes and Staphylococcus aureus, but not against Lactobacillus plantarum and Salmonella Typhimurium. Hydrogel coatings have been also proposed to reduce the deterioration of fresh fruit, meat or fish, as they can provide a semi-permeable protection to gases and water vapour and some other environmental factors that could damage food. By promoting food perspiration, these films also help to reduce enzymatic browning and water loss. Furthermore, this protection may also be enhanced by the addition of other 
ingredients, such as minerals, antioxidants, nutrients, vitamins or probiotics [109]. On the other hand, when the extraction of solvents at their supercritical state is produced in hydrogels or alcogels, the resultant material is called aerogels. Due to their unique properties, such as high porosity, high specific surface area, low relative density and thermal conductivity, these pectin-based biopolymers represent an innovative approach as advanced materials for food packaging since they can be used as internal layers, oxygen scavengers or drug delivery systems [110,111]. Recently, pectin-based aerogels have been developed for the storage of temperature-sensitive food. In this regard, $\mathrm{TiO}_{2}$ nanoparticles were incorporated into the pectin matrix to improve the mechanical, thermal and antimicrobial properties of pectin when compared to control films [86].

As it has been mentioned above, pectin can be used as nanoemulsions, which are kinetically stable, but thermodynamically unstable, systems whose production requires emulsifiers to stabilize the dispersed phase [93]. Different types of essential oils have been encapsulated using nanoemulsions to delay and control the release processes. Several authors have studied the use of nanoemulsions in pectin matrices with different essential oils extracted from curcumin [91], lemongrass [92,93] and oregano [92]. Although essential oils are especially interesting in food packaging applications due to their antioxidant and/or antimicrobial properties, Mendes et al. [93] incorporated pectin nanoemulsions with the lemongrass essential oil into cassava starch film to improve the biodegradation rate of these formulations. Results obtained for the film with nanoemulsions showed a suitable degradation in vegetal compost, ensuring their complete biodegradation in a short time increasing their potential application in the food industry.

\section{Conclusions}

Researchers and scientists have achieved great success in the development of new systems based on pectins, as a natural bio-based biopolymer that can be obtained from agro-waste products, contributing to the implementation of the circular economy concept by improving waste management. This review article has considered the latest results obtained by researchers on the extraction, functionalization and potential applications in the food industry (including packaging), such as the production of films, emulsions and gels. However, due to the variability in the pectin structure the final application of pectin matrices is very diverse but very promising in many fields related to food packaging, particularly when active formulations are searched. Further studies on pectin matrices and optimization of polymer processes will be needed to better control the resulting pectin-based products.

Author Contributions: Conceptualization: C.M., M.R., A.J. and M.C.G.; methodology: C.M., M.R., A.J. and M.C.G.; formal analysis, discussion and supervision: C.M., M.R., A.J. and M.C.G. All authors have read and agreed to the published version of the manuscript.

Funding: This research received no external funding.

Acknowledgments: Authors would like to thank the Spanish Ministry of Science, Innovation and Universities for their support through the project referenced MAT2017-84909-C2-1-R.

Conflicts of Interest: The authors declare no conflict of interest.

\section{References}

1. Jha, A.; Kumar, A. Biobased technologies for the efficient extraction of biopolymers from waste biomass. Bioprocess Biosyst. Eng. 2019, 42, 1893-1901. [CrossRef] [PubMed]

2. Martău, G.A.; Mihai, M.; Vodnar, D.C. The Use of Chitosan, Alginate, and Pectin in the Biomedical and Food Sector-Biocompatibility, Bioadhesiveness, and Biodegradability. Polymers 2019, 11, 1837. [CrossRef] [PubMed]

3. Adhikari, B.B.; Chae, M.; Bressler, D.C. Utilization of slaughterhouse waste in value-added applications: Recent advances in the development of wood adhesives. Polymers 2018, 10, 176. [CrossRef]

4. Nishinari, K.; Fang, Y.; Guo, S.; Phillips, G.O. Soy proteins: A review on composition, aggregation and emulsification. Food Hydrocoll. 2014, 39, 301-318. [CrossRef] 
5. Benítez, J.J.; Castillo, P.M.; del Río, J.C.; León-Camacho, M.; Domínguez, E.; Heredia, A.; Guzmán-Puyol, S.; Athanassiou, A.; Heredia-Guerrero, J.A. Valorization of Tomato Processing by-Products: Fatty Acid Extraction and Production of Bio-Based Materials. Materials 2018, 11, 2211. [CrossRef]

6. Tran, D.-T.; Lee, H.R.; Jung, S.; Park, M.S.; Yang, J.-W. Lipid-extracted algal biomass based biocomposites fabrication with poly(vinyl alcohol). Algal Res. 2018, 31, 525-533. [CrossRef]

7. Damm, T.; Commandeur, U.; Fischer, R.; Usadel, B.; Klose, H. Improving the utilization of lignocellulosic biomass by polysaccharide modification. Process Biochem. 2016, 51, 288-296. [CrossRef]

8. Valdés, A.; Mellinas, A.C.; Ramos, M.; Garrigós, M.C.; Jiménez, A. Natural additives and agricultural wastes in biopolymer formulations for food packaging. Front. Chem. 2014, 2. [CrossRef]

9. Shankar, S.; Tanomrod, N.; Rawdkuen, S.; Rhim, J.-W. Preparation of pectin/silver nanoparticles composite films with UV-light barrier and properties. Int. J. Biol. Macromol. 2016, 92, 842-849. [CrossRef] [PubMed]

10. da Silva, I.S.V.; de Sousa, R.M.F.; de Oliveira, A.; de Oliveira, W.J.; Motta, L.A.C.; Pasquini, D.; Otaguro, H.; da Silva, I.S.V.; de Sousa, R.M.F.; de Oliveira, A.; et al. Polymeric blends of hydrocolloid from chia seeds/apple pectin with potential antioxidant for food packaging applications. Carbohydr. Polym. 2018, 202, $203-210$. [CrossRef]

11. Correa, J.P.; Molina, V.; Sanchez, M.; Kainz, C.; Eisenberg, P.; Massani, M.B. Improving ham shelf life with a polyhydroxybutyrate/polycaprolactone biodegradable film activated with nisin. Food Packag. Shelf Life 2017, 11,31-39. [CrossRef]

12. Xia, C.; Wang, W.; Wang, L.; Liu, H.; Xiao, J. Multilayer zein/gelatin films with tunable water barrier property and prolonged antioxidant activity. Food Packag. Shelf Life 2019, 19, 76-85. [CrossRef]

13. Wang, H.; Gong, X.; Miao, Y.; Guo, X.; Liu, C.; Fan, Y.-Y.; Zhang, J.; Niu, B.; Li, W. Preparation and characterization of multilayer films composed of chitosan, sodium alginate and carboxymethyl chitosan-ZnO nanoparticles. Food Chem. 2019, 283, 397-403. [CrossRef] [PubMed]

14. Mellinas, C.; Valdés, A.; Ramos, M.; Burgos, N.; Del Carmen Garrigós, M.; Jiménez, A. Active edible films: Current state and future trends. J. Appl. Polym. Sci. 2016, 133. [CrossRef]

15. Abdul Khalil, H.P.S.; Chong, E.W.N.; Owolabi, F.A.T.; Asniza, M.; Tye, Y.Y.; Rizal, S.; Nurul Fazita, M.R.; Mohamad Haafiz, M.K.; Nurmiati, Z.; Paridah, M.T. Enhancement of basic properties of polysaccharide-based composites with organic and inorganic fillers: A review. J. Appl. Polym. Sci. 2019, 136. [CrossRef]

16. Rodsamran, P.; Sothornvit, R. Lime peel pectin integrated with coconut water and lime peel extract as a new bioactive film sachet to retard soybean oil oxidation. Food Hydrocoll. 2019, 97. [CrossRef]

17. Sun, X.; Cameron, R.G.; Bai, J. Effect of spray-drying temperature on physicochemical, antioxidant and antimicrobial properties of pectin/sodium alginate microencapsulated carvacrol. Food Hydrocoll. 2020, 100. [CrossRef]

18. de Oliveira Alves Sena, E.; Oliveira da Silva, P.S.; de Aragão Batista, M.C.; Alonzo Sargent, S.; Ganassali de Oliveira Junior, L.F.; Almeida Castro Pagani, A.; Gutierrez Carnelossi, M.A. Calcium application via hydrocooling and edible coating for the conservation and quality of cashew apples. Sci. Hortic 2019, 256. [CrossRef]

19. Sucheta; Chaturvedi, K.; Sharma, N.; Yadav, S.K. Composite edible coatings from commercial pectin, corn flour and beetroot powder minimize post-harvest decay, reduces ripening and improves sensory liking of tomatoes. Int. J. Biol. Macromol. 2019, 133, 284-293. [CrossRef]

20. Pizato, S.; Chevalier, R.C.; Dos Santos, M.F.; Da Costa, T.S.; Arévalo Pinedo, R.; Cortez Vega, W.R. Evaluation of the shelf-life extension of fresh-cut pineapple (Smooth cayenne) by application of different edible coatings. Br. Food J. 2019, 121, 1592-1604. [CrossRef]

21. Jiang, Y.; Li, F.; Li, D.; Sun-Waterhouse, D.; Huang, Q. Zein/Pectin Nanoparticle-Stabilized Sesame Oil Pickering Emulsions: Sustainable Bioactive Carriers and Healthy Alternatives to Sesame Paste. Food Bioprocess Technol. 2019, 12, 1982-1992. [CrossRef]

22. Noreen, A.; Nazli, Z.-H.; Akram, J.; Rasul, I.; Mansha, A.; Yaqoob, N.; Iqbal, R.; Tabasum, S.; Zuber, M.; Zia, K.M. Pectins functionalized biomaterials; a new viable approach for biomedical applications: A review. Int. J. Biol. Macromol. 2017, 101, 254-272. [CrossRef] [PubMed]

23. Mohnen, D. Pectin structure and biosynthesis. Curr. Opin. Plant Biol. 2008, 11, 266-277. [CrossRef] [PubMed]

24. Naqash, F.; Masoodi, F.A.; Rather, S.A.; Wani, S.M.; Gani, A. Emerging concepts in the nutraceutical and functional properties of pectin-A Review. Carbohydr. Polym. 2017, 168, 227-239. [CrossRef] 
25. O'Neill, M.A.; Ishii, T.; Albersheim, P.; Darvill, A.G. RHAMNOGALACTURONAN II: Structure and Function of a Borate Cross-Linked Cell Wall Pectic Polysaccharide. Annu. Rev. Plant Biol. 2004, 55, 109-139. [CrossRef]

26. Voragen, A.G.J.; Coenen, G.J.; Verhoef, R.P.; Schols, H.A. Pectin, a versatile polysaccharide present in plant cell walls. Struct. Chem. 2009, 20, 263-275. [CrossRef]

27. Sañudo Barajas, J.A.; Ayón, M.; Velez, R.; Verdugo-Perales, M.; Lagarda, J.; Allende, R. Pectins: From the Gelling Properties to the Biological Activity; Nova Publishers: Hauppauge, NY, USA, 2014; pp. 203-224.

28. Morales-Contreras, B.E.; Rosas-Flores, W.; Contreras-Esquivel, J.C.; Wicker, L.; Morales-Castro, J. Pectin from Husk Tomato (Physalis ixocarpa Brot.): Rheological behavior at different extraction conditions. Carbohydr. Polym. 2018, 179, 282-289. [CrossRef]

29. Giacomazza, D.; Bulone, D.; San Biagio, P.L.; Marino, R.; Lapasin, R. The role of sucrose concentration in self-assembly kinetics of high methoxyl pectin. Int. J. Biol. Macromol. 2018, 112, 1183-1190. [CrossRef]

30. do Nascimento, G.E.; Simas-Tosin, F.F.; Iacomini, M.; Gorin, P.A.J.; Cordeiro, L.M.C. Rheological behavior of high methoxyl pectin from the pulp of tamarillo fruit (Solanum betaceum). Carbohydr. Polym. 2016, 139, 125-130. [CrossRef]

31. Giacomazza, D.; Bulone, D.; San Biagio, P.L.; Lapasin, R. The complex mechanism of HM pectin self-assembly: A rheological investigation. Carbohydr. Polym. 2016, 146, 181-186. [CrossRef]

32. Wang, H.; Wan, L.; Chen, D.; Guo, X.; Liu, F.; Pan, S. Unexpected gelation behavior of citrus pectin induced by monovalent cations under alkaline conditions. Carbohydr. Polym. 2019, 212, 51-58. [CrossRef] [PubMed]

33. Jiang, W.; Qi, J.-R.; Huang, Y.; Zhang, Y.; Yang, X.-Q. Emulsifying properties of high methoxyl pectins in binary systems of water-ethanol. Carbohydr. Polym. 2020, 229, 115420. [CrossRef] [PubMed]

34. Fishman, M.L.; Chau, H.K.; Qi, P.X.; Hotchkiss, A.T.; Garcia, R.A.; Cooke, P.H. Characterization of the global structure of low methoxyl pectin in solution. Food Hydrocoll. 2015, 46, 153-159. [CrossRef]

35. Han, W.; Meng, Y.; Hu, C.; Dong, G.; Qu, Y.; Deng, H.; Guo, Y. Mathematical model of Ca ${ }^{2+}$ concentration, $\mathrm{pH}$, pectin concentration and soluble solids (sucrose) on the gelation of low methoxyl pectin. Food Hydrocoll. 2017, 66, 37-48. [CrossRef]

36. Yang, X.; Nisar, T.; Liang, D.; Hou, Y.; Sun, L.; Guo, Y. Low methoxyl pectin gelation under alkaline conditions and its rheological properties: Using $\mathrm{NaOH}$ as a $\mathrm{pH}$ regulator. Food Hydrocoll. 2018, 79, 560-571. [CrossRef]

37. Kazemi, M.; Khodaiyan, F.; Hosseini, S.S.; Najari, Z. An integrated valorization of industrial waste of eggplant: Simultaneous recovery of pectin, phenolics and sequential production of pullulan. Waste Manag. 2019, 100, 101-111. [CrossRef]

38. Senit, J.J.; Velasco, D.; Gomez Manrique, A.; Sanchez-Barba, M.; Toledo, J.M.; Santos, V.E.; Garcia-Ochoa, F.; Yustos, P.; Ladero, M. Orange peel waste upstream integrated processing to terpenes, phenolics, pectin and monosaccharides: Optimization approaches. Ind. Crops Prod. 2019, 134, 370-381. [CrossRef]

39. Hilali, S.; Fabiano-Tixier, A.S.; Ruiz, K.; Hejjaj, A.; Ait Nouh, F.; Idlimam, A.; Bily, A.; Mandi, L.; Chemat, F. Green Extraction of Essential Oils, Polyphenols, and Pectins from Orange Peel Employing Solar Energy: Toward a Zero-Waste Biorefinery. ACS Sustain. Chem. Eng. 2019, 7, 11815-11822. [CrossRef]

40. Tovar, A.K.; Godínez, L.A.; Espejel, F.; Ramírez-Zamora, R.-M.; Robles, I. Optimization of the integral valorization process for orange peel waste using a design of experiments approach: Production of high-quality pectin and activated carbon. Waste Manag. 2019, 85, 202-213. [CrossRef]

41. Roy, M.C.; Alam, M.; Saeid, A.; Das, B.C.; Mia, M.B.; Rahman, M.A.; Eun, J.B.; Ahmed, M. Extraction and characterization of pectin from pomelo peel and its impact on nutritional properties of carrot jam during storage. J. Food Process. Preserv. 2018, 42, 1-9. [CrossRef]

42. Shakhmatov, E.G.; Makarova, E.N.; Belyy, V.A. Structural studies of biologically active pectin-containing polysaccharides of pomegranate Punica granatum. Int. J. Biol. Macromol. 2019, 122, 29-36. [CrossRef] [PubMed]

43. Cho, E.-H.; Jung, H.-T.; Lee, B.-H.; Kim, H.-S.; Rhee, J.-K.; Yoo, S.-H. Green process development for apple-peel pectin production by organic acid extraction. Carbohydr. Polym. 2019, 204, 97-103. [CrossRef] [PubMed]

44. Tamiello-Rosa, C.S.; Cantu-Jungles, T.M.; Iacomini, M.; Cordeiro, L.M.C. Pectins from cashew apple fruit (Anacardium occidentale): Extraction and chemical characterization. Carbohydr. Res. 2019, 483, 107752. [CrossRef] [PubMed]

45. Slavov, A.; Yantcheva, N.; Vasileva, I. Chamomile Wastes (Matricaria chamomilla): New Source of Polysaccharides. Waste Biomass Valor. 2018, 10, 1-12. [CrossRef] 
46. Hasem, N.H.; Mohamad Fuzi, S.F.Z.; Kormin, F.; Abu Bakar, M.F.; Sabran, S.F. Extraction and partial characterization of durian rind pectin. IOP Conf. Ser. Earth Environ. Sci. 2019, 269, 012019. [CrossRef]

47. Esparza-Merino, R.M.; Macías-Rodríguez, M.E.; Cabrera-Díaz, E.; Valencia-Botín, A.J.; Estrada-Girón, Y. Utilization of by-products of Hibiscus sabdariffa L. as alternative sources for the extraction of high-quality pectin. Food Sci. Biotechnol. 2019, 28, 1003-1011. [CrossRef]

48. Marenda, F.R.B.; Colodel, C.; Canteri, M.H.G.; de Olivera Müller, C.M.; Amante, E.R.; de Oliveira Petkowicz, C.L.; de Mello Castanho Amboni, R.D. Investigation of cell wall polysaccharides from flour made with waste peel from unripe banana (Musa sapientum) biomass. J. Sci. Food Agric. 2019, 99, 4363-4372. [CrossRef]

49. Maneerat, N.; Tangsuphoom, N.; Nitithamyong, A. Effect of extraction condition on properties of pectin from banana peels and its function as fat replacer in salad cream. J. Food Sci. Technol. 2017, 54, 386-397. [CrossRef]

50. Banerjee, J.; Singh, R.; Vijayaraghavan, R.; MacFarlane, D.; Patti, A.F.; Arora, A. A hydrocolloid based biorefinery approach to the valorisation of mango peel waste. Food Hydrocoll. 2018, 77, 142-151. [CrossRef]

51. Li, W.J.; Fan, Z.G.; Wu, Y.Y.; Jiang, Z.G.; Shi, R.C. Eco-friendly extraction and physicochemical properties of pectin from jackfruit peel waste with subcritical water. J. Sci. Food Agric. 2019, 99. [CrossRef]

52. Sundarraj, A.A.; Thottiam Vasudevan, R.; Sriramulu, G. Optimized extraction and characterization of pectin from jackfruit (Artocarpus integer) wastes using response surface methodology. Int. J. Biol. Macromol. 2018, 106, 698-703. [CrossRef] [PubMed]

53. Fazio, A.; La Torre, C.; Dalena, F.; Plastina, P. Screening of glucan and pectin contents in broad bean (Vicia faba L.) pods during maturation. Eur. Food Res. Technol. 2019, 246, 333-347. [CrossRef]

54. Inayati, I.; Puspita, R.I.; Fajrin, V.L. Extraction of pectin from passion fruit rind (Passiflora edulis var. flavicarpa Degener) for edible coating. AIP Conf. Proc. 2018, 1931. [CrossRef]

55. Meneguzzo, F.; Brunetti, C.; Fidalgo, A.; Ciriminna, R.; Delisi, R.; Albanese, L.; Zabini, F.; Gori, A.; dos Santos Nascimento, L.B.; De Carlo, A.; et al. Real-Scale Integral Valorization of Waste Orange Peel via Hydrodynamic Cavitation. Processes 2019, 7, 581. [CrossRef]

56. Sabater, C.; Corzo, N.; Olano, A.; Montilla, A. Enzymatic extraction of pectin from artichoke (Cynara scolymus L.) by-products using Celluclast@1.5L. Carbohydr. Polym. 2018, 190, 43-49. [CrossRef] [PubMed]

57. Yang, Y.; Wang, Z.; Hu, D.; Xiao, K.; Wu, J.-Y. Efficient extraction of pectin from sisal waste by combined enzymatic and ultrasonic process. Food Hydrocoll. 2018, 79, 189-196. [CrossRef]

58. Zhang, M.; Zeng, G.; Pan, Y.; Qi, N. Difference research of pectins extracted from tobacco waste by heat reflux extraction and microwave-assisted extraction. Biocatal. Agric. Biotechnol. 2018, 15, 359-363. [CrossRef]

59. Muñoz-Almagro, N.; Valadez-Carmona, L.; Mendiola, J.A.; Ibáñez, E.; Villamiel, M. Structural characterisation of pectin obtained from cacao pod husk. Comparison of conventional and subcritical water extraction. Carbohydr. Polym. 2019, 217, 69-78. [CrossRef]

60. Shivamathi, C.S.; Moorthy, I.G.; Kumar, R.V.; Soosai, M.R.; Maran, J.P.; Kumar, R.S.; Varalakshmi, P. Optimization of ultrasound assisted extraction of pectin from custard apple peel: Potential and new source. Carbohydr. Polym. 2019, 225, 115240. [CrossRef]

61. Guandalini, B.B.V.; Rodrigues, N.P.; Marczak, L.D.F. Sequential extraction of phenolics and pectin from mango peel assisted by ultrasound. Food Res. Int. 2019, 119, 455-461. [CrossRef]

62. de Souza, C.G.; Rodrigues, T.H.S.; e Silva, L.M.A.; Ribeiro, P.R.V.; de Brito, E.S. Sequential extraction of flavonoids and pectin from yellow passion fruit rind using pressurized solvent or ultrasound. J. Sci. Food Agric. 2018, 98, 1362-1368. [CrossRef] [PubMed]

63. Xu, S.-Y.; Liu, J.-P.; Huang, X.; Du, L.-P.; Shi, F.-L.; Dong, R.; Huang, X.-T.; Zheng, K.; Liu, Y.; Cheong, K.-L. Ultrasonic-microwave assisted extraction, characterization and biological activity of pectin from jackfruit peel. LWT 2018, 90, 577-582. [CrossRef]

64. Rodsamran, P.; Sothornvit, R. Microwave heating extraction of pectin from lime peel: Characterization and properties compared with the conventional heating method. Food Chem. 2019, 278, 364-372. [CrossRef] [PubMed]

65. Wandee, Y.; Uttapap, D.; Mischnick, P. Yield and structural composition of pomelo peel pectins extracted under acidic and alkaline conditions. Food Hydrocoll. 2019, 87, 237-244. [CrossRef]

66. Lu, F.; Rodriguez-Garcia, J.; Van Damme, I.; Westwood, N.J.; Shaw, L.; Robinson, J.S.; Warren, G.; Chatzifragkou, A.; McQueen Mason, S.; Gomez, L.; et al. Valorisation strategies for cocoa pod husk and its fractions. Curr. Opin. Green Sustain. Chem. 2018, 14, 80-88. [CrossRef] 
67. Maran, J.P.; Swathi, K.; Jeevitha, P.; Jayalakshmi, J.; Ashvini, G. Microwave-assisted extraction of pectic polysaccharide from waste mango peel. Carbohydr. Polym. 2015, 123, 67-71. [CrossRef]

68. Wang, W.; Ma, X.; Jiang, P.; Hu, L.; Zhi, Z.; Chen, J.; Ding, T.; Ye, X.; Liu, D. Characterization of pectin from grapefruit peel: A comparison of ultrasound-assisted and conventional heating extractions. Food Hydrocoll. 2016, 61, 730-739. [CrossRef]

69. Albuquerque, B.R.; Prieto, M.A.; Vazquez, J.A.; Barreiro, M.F.; Barros, L.; Ferreira, I.C.F.R. Recovery of bioactive compounds from Arbutus unedo L. fruits: Comparative optimization study of maceration/microwave/ ultrasound extraction techniques. Food Res. Int. 2018, 109, 455-471. [CrossRef]

70. Raj, S. A Review on Pectin: Chemistry due to General Properties of Pectin and its Pharmaceutical Uses. Sci. Rep. 2012, 1, 550. [CrossRef]

71. Alistair, M.; Stephen, G.O.P. Food Polysaccharides and Their Applications; CRC Press: Boca Raton, FL, USA, 2006.

72. Porta, R.; Di Pierro, P.; Sabbah, M.; Regalado-Gonzales, C.; Mariniello, L.; Kadivar, M.; Arabestani, A. Blend films of pectin and bitter vetch (Vicia ervilia) proteins: Properties and effect of transglutaminase. Innov. Food Sci. Emerg. Technol. 2016, 36, 245-251. [CrossRef]

73. Chiarappa, G.; De’Nobili, M.D.; Rojas, A.M.; Abrami, M.; Lapasin, R.; Grassi, G.; Ferreira, J.A.; Gudiño, E.; de Oliveira, P.; Grassi, M. Mathematical modeling of L-(+)-ascorbic acid delivery from pectin films (packaging) to agar hydrogels (food). J. Food Eng. 2018, 234, 73-81. [CrossRef]

74. Nisar, T.; Wang, Z.-C.; Yang, X.; Tian, Y.; Iqbal, M.; Guo, Y. Characterization of citrus pectin films integrated with clove bud essential oil: Physical, thermal, barrier, antioxidant and antibacterial properties. Int. J. Biol. Macromol. 2018, 106, 670-680. [CrossRef] [PubMed]

75. Almasi, H.; Azizi, S.; Amjadi, S. Development and characterization of pectin films activated by nanoemulsion and Pickering emulsion stabilized marjoram (Origanum majorana L.) essential oil. Food Hydrocoll. 2020, 99, 105338. [CrossRef]

76. Lei, Y.; Wu, H.; Jiao, C.; Jiang, Y.; Liu, R.; Xiao, D.; Lu, J.; Zhang, Z.; Shen, G.; Li, S. Investigation of the structural and physical properties, antioxidant and antimicrobial activity of pectin-konjac glucomannan composite edible films incorporated with tea polyphenol. Food Hydrocoll. 2019, 94, 128-135. [CrossRef]

77. Lee, J.H.; Jeong, D.; Kanmani, P. Study on physical and mechanical properties of the biopolymer/silver based active nanocomposite films with antimicrobial activity. Carbohydr. Polym. 2019, 224, 115159. [CrossRef] [PubMed]

78. Akhter, R.; Masoodi, F.A.; Wani, T.A.; Rather, S.A. Functional characterization of biopolymer based composite film: Incorporation of natural essential oils and antimicrobial agents. Int. J. Biol. Macromol. 2019, 137, 1245-1255. [CrossRef] [PubMed]

79. Bermúdez-Oria, A.; Rodríguez-Gutiérrez, G.; Rubio-Senent, F.; Fernández-Prior, Á.; Fernández-Bolaños, J. Effect of edible pectin-fish gelatin films containing the olive antioxidants hydroxytyrosol and 3,4-dihydroxyphenylglycol on beef meat during refrigerated storage. Meat Sci. 2019, 148, 213-218. [CrossRef]

80. Dudnyk, I.; Janeček, E.-R.; Vaucher-Joset, J.; Stellacci, F. Edible sensors for meat and seafood freshness. Sens. Actuators B Chem. 2018, 259, 1108-1112. [CrossRef]

81. Maciel, V.B.V.; Yoshida, C.M.P.; Franco, T.T. Chitosan/pectin polyelectrolyte complex as a pH indicator. Carbohydr. Polym. 2015, 132, 537-545. [CrossRef]

82. Vishnuvarthanan, M.; Rajeswari, N. Food packaging: Pectin—laponite-Ag nanoparticle bionanocomposite coated on polypropylene shows low $\mathrm{O} 2$ transmission, low Ag migration and high antimicrobial activity. Environ. Chem. Lett. 2019, 17, 439-445. [CrossRef]

83. Yu, N.; Peng, H.; Qiu, L.; Wang, R.; Jiang, C.; Cai, T.; Sun, Y.; Li, Y.; Xiong, H. New pectin-induced green fabrication of $\mathrm{Ag} @ \mathrm{AgCl} / \mathrm{ZnO}$ nanocomposites for visible-light triggered antibacterial activity. Int. J. Biol. Macromol. 2019, 141, 207-217. [CrossRef] [PubMed]

84. Li, K.; Cui, S.; Hu, J.; Zhou, Y.; Liu, Y. Crosslinked pectin nanofibers with well-dispersed Ag nanoparticles: Preparation and characterization. Carbohydr. Polym. 2018, 199, 68-74. [CrossRef] [PubMed]

85. McCune, D.; Guo, X.; Shi, T.; Stealey, S.; Antrobus, R.; Kaltchev, M.; Chen, J.; Kumpaty, S.; Hua, X.; Ren, W.; et al. Electrospinning pectin-based nanofibers: A parametric and cross-linker study. Appl. Nanosci. 2018, 8, 33-40. [CrossRef] 
86. Nešić, A.; Gordić, M.; Davidović, S.; Radovanović, Ž.; Nedeljković, J.; Smirnova, I.; Gurikov, P. Pectin-based nanocomposite aerogels for potential insulated food packaging application. Carbohydr. Polym. 2018, 195, 128-135. [CrossRef] [PubMed]

87. Torpol, K.; Sriwattana, S.; Sangsuwan, J.; Wiriyacharee, P.; Prinyawiwatkul, W. Optimising chitosan-pectin hydrogel beads containing combined garlic and holy basil essential oils and their application as antimicrobial inhibitor. Int. J. Food Sci. Technol. 2019, 54, 2064-2074. [CrossRef]

88. Luo, S.-Z.; Hu, X.-F.; Jia, Y.-J.; Pan, L.-H.; Zheng, Z.; Zhao, Y.-Y.; Mu, D.-D.; Zhong, X.-Y.; Jiang, S.-T. Camellia oil-based oleogels structuring with tea polyphenol-palmitate particles and citrus pectin by emulsion-templated method: Preparation, characterization and potential application. Food Hydrocoll. 2019, 95, 76-87. [CrossRef]

89. Nisar, T.; Yang, X.; Alim, A.; Iqbal, M.; Wang, Z.-C.; Guo, Y. Physicochemical responses and microbiological changes of bream (Megalobrama ambycephala) to pectin based coatings enriched with clove essential oil during refrigeration. Int. J. Biol. Macromol. 2019, 124, 1156-1166. [CrossRef]

90. Gong, C.; Lee, M.C.; Godec, M.; Zhang, Z.; Abbaspourrad, A. Ultrasonic encapsulation of cinnamon flavor to impart heat stability for baking applications. Food Hydrocoll. 2020, 99, 105316. [CrossRef]

91. Abdou, E.S.; Galhoum, G.F.; Mohamed, E.N. Curcumin loaded nanoemulsions/pectin coatings for refrigerated chicken fillets. Food Hydrocoll. 2018, 83, 445-453. [CrossRef]

92. Guerra-Rosas, M.I.; Morales-Castro, J.; Cubero-Márquez, M.A.; Salvia-Trujillo, L.; Martín-Belloso, O. Antimicrobial activity of nanoemulsions containing essential oils and high methoxyl pectin during long-term storage. Food Control 2017, 77, 131-138. [CrossRef]

93. Mendes, J.F.; Norcino, L.B.; Martins, H.H.A.; Manrich, A.; Otoni, C.G.; Carvalho, E.E.N.; Piccoli, R.H.; Oliveira, J.E.; Pinheiro, A.C.M.; Mattoso, L.H.C. Correlating emulsion characteristics with the properties of active starch films loaded with lemongrass essential oil. Food Hydrocoll. 2020, 100, 105428. [CrossRef]

94. Liu, C.; Tan, Y.; Xu, Y.; McCleiments, D.J.; Wang, D. Formation, characterization, and application of chitosan/pectin-stabilized multilayer emulsions as astaxanthin delivery systems. Int. J. Biol. Macromol. 2019, 140, 985-997. [CrossRef] [PubMed]

95. Sganzerla, W.G.; Paes, B.B.; Azevedo, M.S.; Ferrareze, J.P.; da Rosa, C.G.; Nunes, M.R.; Veeck, A.P.L. Bioactive and biodegradable film packaging incorporated with acca sellowiana extracts: physicochemical and antioxidant characterization. Chem. Eng. Trans. 2019, 75, 445-450.

96. Spatafora Salazar, A.S.; Sáenz Cavazos, P.A.; Mújica Paz, H.; Valdez Fragoso, A. External factors and nanoparticles effect on water vapor permeability of pectin-based films. J. Food Eng. 2019, 245, 73-79. [CrossRef]

97. Gorrasi, G. Dispersion of halloysite loaded with natural antimicrobials into pectins: Characterization and controlled release analysis. Carbohydr. Polym. 2015, 127, 47-53. [CrossRef] [PubMed]

98. Bernhardt, D.C.; Pérez, C.D.; Fissore, E.N.; De’Nobili, M.D.; Rojas, A.M. Pectin-based composite film: Effect of corn husk fiber concentration on their properties. Carbohydr. Polym. 2017, 164, 13-22. [CrossRef] [PubMed]

99. Gouveia, T.I.A.; Biernacki, K.; Castro, M.C.R.; Gonçalves, M.P.; Souza, H.K.S. A new approach to develop biodegradable films based on thermoplastic pectin. Food Hydrocoll. 2019, 97, 105175. [CrossRef]

100. Manrich, A.; Moreira, F.K.V.; Otoni, C.G.; Lorevice, M.V.; Martins, M.A.; Mattoso, L.H.C. Hydrophobic edible films made up of tomato cutin and pectin. Carbohydr. Polym. 2017, 164, 83-91. [CrossRef]

101. Gao, H.-X.; He, Z.; Sun, Q.; He, Q.; Zeng, W.-C. A functional polysaccharide film forming by pectin, chitosan, and tea polyphenols. Carbohydr. Polym. 2019, 215, 1-7. [CrossRef]

102. Ramos, M.; Fortunati, E.; Peltzer, M.; Kenny, J.M.; Garrigós, M.C. Characterization and disintegrability under composting conditions of PLA-based nanocomposite films with thymol and silver nanoparticles. Polym. Degrad. Stab. 2016, 132, 2-10. [CrossRef]

103. Dash, K.K.; Ali, N.A.; Das, D.; Mohanta, D. Thorough evaluation of sweet potato starch and lemon-waste pectin based-edible films with nano-titania inclusions for food packaging applications. Int. J. Biol. Macromol. 2019, 139, 449-458. [CrossRef]

104. Makaremi, M.; Pasbakhsh, P.; Cavallaro, G.; Lazzara, G.; Aw, Y.K.; Lee, S.M.; Milioto, S. Effect of Morphology and Size of Halloysite Nanotubes on Functional Pectin Bionanocomposites for Food Packaging Applications. ACS Appl. Mater. Interfaces 2017, 9, 17476-17488. [CrossRef] [PubMed]

105. Biddeci, G.; Cavallaro, G.; Di Blasi, F.; Lazzara, G.; Massaro, M.; Milioto, S.; Parisi, F.; Riela, S.; Spinelli, G. Halloysite nanotubes loaded with peppermint essential oil as filler for functional biopolymer film. Carbohydr. Polym. 2016, 152, 548-557. [CrossRef] 
106. Groult, S.; Budtova, T. Thermal conductivity/structure correlations in thermal super-insulating pectin aerogels. Carbohydr. Polym. 2018, 196, 73-81. [CrossRef] [PubMed]

107. Mehrali, M.; Thakur, A.; Kadumudi, F.B.; Pierchala, M.K.; Cordova, J.A.V.; Shahbazi, M.-A.; Mehrali, M.; Pennisi, C.P.; Orive, G.; Gaharwar, A.K.; et al. Pectin Methacrylate (PEMA) and Gelatin-Based Hydrogels for Cell Delivery: Converting Waste Materials into Biomaterials. ACS Appl. Mater. Interfaces 2019, 11, 12283-12297. [CrossRef]

108. Wijaya, W.; Sun, Q.-Q.; Vermeir, L.; Dewettinck, K.; Patel, A.R.; Van der Meeren, P. pH and protein to polysaccharide ratio control the structural properties and viscoelastic network of HIPE-templated biopolymeric oleogels. Food Struct. 2019, 21, 100112. [CrossRef]

109. Sanchís, E.; Ghidelli, C.; Sheth, C.C.; Mateos, M.; Palou, L.; Pérez-Gago, M.B. Integration of antimicrobial pectin-based edible coating and active modified atmosphere packaging to preserve the quality and microbial safety of fresh-cut persimmon (Diospyros kaki Thunb. cv. Rojo Brillante). J. Sci. Food Agric. 2017, 97, 252-260. [CrossRef]

110. Ahmadzadeh, S.; Nasirpour, A.; Keramat, J.; Desobry, S. Powerful Solution to Mitigate the Temperature Variation Effect: Development of Novel Superinsulating Materials. Food Packag. Preserv. 2018, 137-176.

111. de Oliveira, J.P.; Bruni, G.P.; el Halal, S.L.M.; Bertoldi, F.C.; Dias, A.R.G.; Zavareze, E.d.R. Cellulose nanocrystals from rice and oat husks and their application in aerogels for food packaging. Int. J. Biol. Macromol. 2019, 124, 175-184. [CrossRef]

(C) 2020 by the authors. Licensee MDPI, Basel, Switzerland. This article is an open access article distributed under the terms and conditions of the Creative Commons Attribution (CC BY) license (http://creativecommons.org/licenses/by/4.0/). 